\title{
The Influence of School Leadership Style and Teacher's Motivation toward Teacher's Performance
}

\author{
Firman \\ SMA Negeri 1 Rambutan \\ e-mail: firman@gmail.com \\ Happy Fitria \\ Universitas PGRI Palembang \\ e-mail: happyfitriamufly@ univpgri-palembang.ac.id \\ Rohana \\ Universitas PGRI Palembang \\ e-mail: rohana@univpgri-palembang.ac.id \\ Article History: Received on 18 March 2021, Revised on 20 March 2021 \\ Published on 27 July 2021
}

\begin{abstract}
The purpose of this study investigated 1) the impact of the Principal's leadership style on results, 2) the effect of motivating teachers on performance, and 3) the effect of the Principal's leadership style and motivation on performance. This research is based on quantitative approaches. The population used all teachers in SMAN 1 and SMKN 1 Rambutan, Banyuasin Regency, South Sumatra Province as samples. Since the research population has only 77 populations and all of them are sampled. Data was analyzed using a simple linear regression formula and multiple linear regression From the results of the study, it can be concluded that (1) the influence of the principal's leadership style on the performance of the SMA-SMK Negeri in the Rambutan Banyuasin district, (2) the influence of the motivation of the teacher on the performance of the SMA-SMK Negeri in the Rambutan Banyuasin district, and (3) the influence of the leadership style of the principal and the motivation of the teacher together.
\end{abstract}

Keywords: Principal Leadership Style, Teacher Motivation, Teacher Performance

\section{A. Introduction}

Schools are represented as the life of a small community, in line with Sagala (2012)'s view that schools are like small communities or mini-societies that become a forum for student growth, not just a bureaucracy full of duties and burdens. A school whose status is the organization that functions to promote the implementation of educational program. Every school must therefore abide by the principles of good governance.

Demonstrating good leadership or good governance requires human resources (teachers) that are developed and qualified in their profession. Human resources (HR) are management and leadership considerations. This aspect is critical in the development and advancement of education, in the name of school-based management or, in other words, school-based management. This is consistent with what Duhou (2012) argues that conceptually school-based management can be defined as a structured shift in the organizational structure, a type of decentralization that defines the school as the key improvement unit. On this basis, the school 
Volume 2 (1) 2021

E-ISSN: 2723-6919 P-ISSN:2746-0827

is obligated to position staff in accordance with their respective competencies in order to achieve educational objectives.

Healthy education can be obtained and achieved. This is expressed in Government Regulation No. 19 of 2005 on National Education Standards (PP No. 19 of 2005), which notes that there are eight standards to be met in the implementation of education. These standards include: quality standards, process standards, graduation competency standards, competency standards for educators and staff, technology and facilities standards, management standards, funding standards, and education evaluation standards.

Quality in education will be improved if any of these requirements are fully applied. The competency level for teachers and educational staff is one of the criteria that must be maintained and improved for the achievement of good education. In line with this, Law No. 14 of 2005 on Teachers and Lecturers Article 1(1) states that 'teachers are vocational educators with the key purpose of educating, teaching, guiding, guiding, preparing, evaluating and evaluating students on the educational route. formal, basic and secondary education.'

Educators or teachers are individuals who have roles and responsibilities in the area of learning and education. In line with this, Tirtarahardja and Sulo (2015) note that teachers are the people responsible for the implementation of education aimed at students. The teacher is an essential factor in learning activities, at least the teacher must have four skills. Pursuant to Regulation No 16 of 2007 of the Minister of National Education concerning qualifications and competencies. Pedagogical competence, personality competence, technical competence and social competence are the four competencies that must be present in teachers. These competencies can indicate the quality of a teacher's performance in carrying out its key tasks and functions.

Solutions to achieve teacher success in the performance of their duties and functions properly require evaluation. This statement is consistent with Hasibuan's view in Barnawi and Arifin (2014) that the evaluation of employee conduct at work, both qualitatively and quantitatively, requires an assessment of the activity. To understand all that includes good governance.

The objective of performance management is to ensure that organizational objectives are well achieved. According to the Dharma (2011), the aim of performance management is a step or a way to achieve the results and efficiency of the organization for both groups and individuals by recognizing and implementing performance in accordance with the objectives, standards and requirements. The competencies that have been determined include the instructor in this situation. As far as teachers are concerned, there are many metrics of teacher success. Based on the above definition, he is responsible for the results obtained by the teacher in carrying out the key tasks and functions of the learning process.

There are three factors that affect success, namely: (1) ability, personality and interest in work. 2) Clarity and appreciation of the clarification of the duties and functions of the worker and acceptance of the tasks assigned to him by the individual. 3) The level of enthusiasm of the worker.

Sujanto (2018) notes that motivation is a phenomenon that cannot be observed, but can be interpreted by the behavior of individuals who behave in such a way that motivation can be assumed to be a mental construction. Motivation, therefore, is a shift in energy in an individual characterized by the appearance of "feelings" and followed by a response to a target. 
The ability to succeed is one of the reasons for everyone (including teachers) to have motivation. Sujanto (2018) notes that people with a high motivation for achievement would try hard to achieve satisfactory results in an activity or a job due to the high capacity and effort of that individual. Relationships in the areas of learning and education, inspiration for success can be seen as a mecca or an example for teachers to increase the standard or quality of results. So, the responsibilities and roles of the instructor are not only instruction, but also the ability to guide actions and behavior patterns in an attempt to achieve the perfection-based achievement of the teacher. A teacher who has motivation, whether consciously or not, would have an effect on the performance of his duties and duties at school.

According to Barnawi and Arifin (2014), motivation comes not only from within an individual, but also from outside factors that influence teacher performance, and leadership is one of these factors. According to Thoha (2019), leadership is often defined as the exercise of authority and decision making.

In other words, leadership is the ability to move one's own, as well as the ability to control, the ability to inspire, to be good at welcoming and leading others, to advise and foster, to guide and educate, and to order and command as well as forbid and even punish members of the organization, both as groups and individuals.

In other words, leadership is the ability to move one's own as well as the ability to influence, the ability to motivate, the ability to invite and direct someone, the ability to advise and foster, the ability to guide and train, and the ability to command and command as well as prohibit and even punish with the intention that members, both as groups and individuals who are part of the organization, are willing to work. This is closely linked to the principal's leadership style.

The position of leadership is carried out by the principal in schools or educational institutions. As a chief, the principal is obligated or must be capable of skillfully or consistently steering the company in a new strategic direction. A leader is inextricably linked to leadership. Only a leader can carry out this leadership. As a consequence, a leader is someone who has the ability to lead, as well as the ability to manipulate the status of another person or a group of people in order to achieve predetermined goals. It is claimed that in the sense of Human Resource Management, someone who has responsibility for quality or HR quality needs skills in the following areas: it is said that in the sense of Human Resource Management (HRM), someone who has responsibility for quality or HR quality needs management skills in the form of leadership, since leadership is the guiding force of all the resources and tools available to them. a corporation (Sagala, 2012).

The principal's leadership style is very influential and influences the school's success, including inspiring teachers to do well in carrying out their duties. As a result, one of the most critical factors to consider when designing internal apparatus resources is leadership. This means that the leader as a government is concerned with all facets of the leadership of a specific entity or agency's contribution to enhancing the overall quality of human capital in an organization. Optimization as an initiative of organizational and government officials, in this case State Senior High School 1 Rambutan and State Vocational High School 1 Rambutan, necessitates efforts to support all facets of current human resource growth. 
Volume 2 (1) 2021

E-ISSN: 2723-6919 P-ISSN:2746-0827

According to Ramadoni (2014), the principal is an educational leader who is responsible for establishing a conducive learning atmosphere in order to optimize the capacity of teachers, staff, and students. The principal motivates teachers to be more involved in carrying out their performance, which involves preparing, implementing, and evaluating.

According to initial findings at SMAN 1 and SMKN 1 Rambutan, the principal (leader) does not inspire teachers (subordinates) to do a good job. This fact demonstrates that there is a disconnect between the principal (highest leader) and the teacher (members or related parties), resulting in the process and objectives not working optimally, despite the fact that, in the researcher's opinion, the styles used by school principals in leading schools are very diverse. The preliminary findings of this study indicate that there is an indication issue that demonstrates teachers' poor performance in preparing learning resources in the form of RPP (Learning Implementation Plan), one of the performance measures in lesson planning. Furthermore, it appears that the teacher is still not optimal in the implementation of learning, suggesting that workplace discipline is still poor. This is illustrated in the table below:

Table 1.

Teacher Performance Data of SMAN 1 and SMKN 1 Rambutan Based on the Preparation of RPP for the 2019/2020 Learning Year (\%)

\begin{tabular}{|c|l|l|c|}
\hline \multirow{2}{*}{ No. } & \multicolumn{1}{|c|}{ School } & \multicolumn{1}{|c|}{$\begin{array}{c}\text { Preparation of } \\
\text { RPP }\end{array}$} & LY. 2019/2020 \\
\hline \multirow{2}{*}{1} & \multirow{2}{*}{ SMAN 1 Rambutan } & Compose & $45 \%$ \\
\cline { 3 - 4 } & & Does not compose & $55 \%$ \\
\hline \multirow{2}{*}{2} & \multirow{2}{*}{ SMKN 1 Rambutan } & Menyusun & $65 \%$ \\
\cline { 3 - 4 } & & Compose & $35 \%$ \\
\hline
\end{tabular}

Source: Deputy for Curriculum for SMAN 1 and SMKN 1 Rambutan

The table above compares SMAN 1 Rambutan and SMKN 1 Rambutan in the preparation of lesson plans by subject teachers, indicating poor teacher performance in the 2019/2020 school year, since more teachers do not prepare lesson plans at SMAN 1 Rambutan. Aside from indicating poor teacher results, the data above may also indicate the principal's leadership style, which does not offer solutions to subordinates in the problem of subject teachers preparing lesson plans.

According to Mc. Donald in Sardiman, motivation is a shift in energy in an individual marked by the appearance of "feelings" and is followed by a response to a target (2012). Hadari Nawawi in Kurniadin and Machali (2014) state that motivation is rooted in motive, which implies the motivation for someone to do something, which is normally manifested in a person's various behaviors. Motivation is the driving force that drives someone to contribute as much as possible to the success of the organization in achieving its objectives, with the idea that achieving company goals requires achieving the personal goals of the company's members. Danim (2012) state that motivation is the power, drive, need, excitement, strain, or psychological mechanism that encourages an individual or group of people to achieve certain goals.

According to the researcher, what is meant by motivation is the urge that is in a person, whether it is the impulse that is inside a person or the impulse that comes from outside himself, to make a set of attempts to accomplish goals and reach his objectives. 
Table 2.

Percentage of Attendance at SMAN 1 and SMKN 1 Rambutan Teachers Learning Year 2019/2020 (\%)

\begin{tabular}{|c|l|l|c|}
\hline \multirow{2}{*}{ No. } & \multicolumn{1}{|c|}{ School } & \multicolumn{1}{c|}{$\begin{array}{c}\text { Category } \\
\text { Teacher Absence }\end{array}$} & \multirow{2}{*}{ LY. 2019/2020 } \\
\hline \multirow{2}{*}{1} & \multirow{2}{*}{ SMAN 1 Rambutan } & There is a description & $43 \%$ \\
\cline { 3 - 4 } & & Without explanation & $57 \%$ \\
\hline \multirow{2}{*}{2} & \multirow{2}{*}{ SMKN 1 Rambutan } & There is a description & $62 \%$ \\
\cline { 3 - 4 } & & Without explanation & $38 \%$ \\
\hline
\end{tabular}

Source: Administration (TU) of SMAN 1 and SMKN 1 Rambutan

The data in the table above show a comparison between SMAN 1 Rambutan and SMKN 1 Rambutan in the participation of teachers in the learning process, indicating that low teacher output in the 2019/2020 school year is more prevalent in SMAN 1 Rambutan.

This image combines three metrics, the first of which suggests that teacher performance is poor. Teachers are not disciplined to work in their presence, even though it is very influential or directly connected to the teacher's work. If the instructor always fails to show up for work, the quality of the work they receive will suffer. Furthermore, the lack of discipline in the teacher's workplace is high, indicating the teacher's low motivation. Finally, it is possible that the principal's leadership style could reduce teacher efficiency and encouragement in carrying out its primary tasks and functions. As a result, the principal must be at the forefront of inspiring teachers.

In light of the preceding clarification, it is clear that the position of the principal should be capable of inspiring teachers to achieve educational goals. This aims to provide a summary of a principal's position and strategy for increasing teacher job motivation. This aims to provide a summary of a principal's position and strategy for increasing teacher job motivation. It will have an effect on educational performance, either directly or indirectly, including at SMAN 1 and SMKN 1 Rambutan.

Based on the data presented above, the suitability of the data for the discussion that the researcher will conduct is the primary reason for researchers to conduct research at SMAN 1 and SMKN 1 Rambutan, in addition to the strategic position because it is near to the researcher's residence and workplace. As a result, the researcher is inspired to address this issue in this report, titled "The Effect of Principal Leadership Style and Teacher Motivation on Teacher Performance in Public Senior High Schools in Rambutan Banyuasin District."

According to Poerwadarminta (2011), success is a way, actions, and work capacity. According to Aritonang in Barnawi and Arifin (2014) success is the work performed by an individual in an organization in compliance with authority and duty in an attempt to achieve the goals to be achieved.

According to Fattah (2019), success is job action, which is what employees do. Meanwhile, Ainsworth, Smith, and Millership in Fattah (2019) describe success as a final result. Performance is the result of a group of individuals, resources, and the world coming together with the goal of creating something, whether tangible goods or less direct services. This aims to provide a summary of a principal's position and strategy for increasing teacher job 
motivation. It will have an effect on educational performance, either directly or indirectly, including at SMAN 1 and SMKN 1 Rambutan.

According to certain experts' and researchers' definitions of success, performance is something that is accomplished by anyone in carrying out their key tasks and functions to achieve the objectives that have been organized in a work unit or organization. In other words, according to researchers, success is closely linked to a person's job performance, and the effects can be in the form of visible goods or services that can only be felt by benefits.

According to Fattah (2011), leadership is a person's capacity or power to influence others in the workplace, with the aim of achieving predetermined organizational goals. A leader has his or her own style for accomplishing this task. According to Sagala (2012), leadership is the skill that a leader possesses in the form of specific characteristics such as personality, ability, and capability. Leadership is a set of behaviors conducted by a leader that cannot be isolated from position. These activities involve the leader's style and behaviour, as well as interactions between the leader, followers, and the situation.

Furthermore, Terry in Sutrisno (2012) describes leadership as an action that motivates people to work together to accomplish shared goals. In other words, leadership is a process of giving sense to mutual action such that there is a willingness to make the required effort to accomplish goals, or activities to influence other people to put more effort into focusing energy in their duties or modifying their actions.

According to the experts' opinions, leadership is an action or procedure carried out to control a group of participants is used to promote individuals in order to achieve collectively planned objectives, in this case the goals of education in their own leadership style.

\section{B. Methods}

According to the context of the problems described earlier, the design of this paper is of the quantitative descriptive kind. Since it is focused on the theory of positivism, quantitative analysis is referred to as a positivistic process. The data required for this study is derived from primary data, which was collected directly from the source. Respondents' questionnaire data was collected.

The population that became the subject of this study were all teachers of SMAN 1 and SMKN 1 Rambutan, specifically the 2019-2020 school year, a total of 77 teachers divided into two classes, namely SMAN 1 Rambutan tang, which consisted of 31 civil servant teachers and 9 students. non-civil servant teachers and 37 SMKN 1 Rambutan teachers, 11 civil servants and 26 non-civil servants. In this case, researchers used both teachers from SMAN 1 and SMKN 1 Rambutan in Banyuasin Regency, South Sumatra Province as samples. Since the research population has only 77 populations and all of them are sampled, this is sufficient according to Emzir's (2014) opinion that the sample for correlational studies can be chosen using an acceptable sampling process, and 30 subjects are considered the minimum acceptable sample size.

This thesis is an empirical study that demonstrates the impact of the motivation variable on the performance of Pekalongan City RA school teachers. The variables investigated in this study were the dependent variable $(Y)$ teacher efficiency, the independent variable $\left(\mathrm{X}_{1}\right)$ the principal's leadership, and the dependent variable $\left(\mathrm{X}_{2}\right)$ motivation. 
The subjects from which data can be collected are the subjects of this study; this data is obtained by distributing questionnaires directly to respondents from the principal and teachers of SMAN 1 and SMKN 1 Rambutan. The questionnaire $\left(\mathrm{X}_{1}\right)$ makes the principal's leadership and $\left(\mathrm{X}_{2}\right)$ motivation a measurement scale, and the measurement scale used to calculate the questionnaire predictor is the LIKERT scale, with the following measurements: often with a score (5), sometimes with a score (4), sometimes with a score (3), less than a score (2), never with a score (1).

\section{Results and Discussion}

This analysis is quantitative in nature, and the findings will be in the form of numbers. The data obtained was analyzed using the SPSS 22 program. The aim of this research is to examine the impact of the Principal's Leadership Style and Teacher Motivation on the Performance of Teachers in SMA-SMK Negeri in Rambutan Banyuasin Sub-District. The data was collected using a questionnaire of 77 respondents, 40 from SMAN 1 Rambutan and 37 from SMKN 1 Rambutan, with the target in mind. The questionnaires were distributed in a closed format, with a Likert scale of 1-5. The data was collected using a questionnaire of 77 respondents, 40 from SMAN 1 Rambutan and 37 from SMKN 1 Rambutan, with the target in mind. The questionnaires were distributed in a closed format, with a Likert scale of 1-5. At SMAN 1 Rambutan and SMKN 1 Rambutan, three variables were used in this study: principal leadership style, teacher motivation, and teacher performance.

The questionnaire is designed in accordance with the variables investigated: 1) the principal's leadership style from the validity test results of 30 statement items for the principal's leadership style variable, the number of valid statements is 22 items; 2) teacher motivation from the validity test results of 30 statements for the job motivation variable, the number of valid statements is 18 items; and 3) the effectiveness of teachers The number of correct statements is 21 based on the findings of the validity test of 30 statements for teacher evaluation variables.

\section{1) The impact of the principal's management style on teacher results}

The findings revealed a relationship between variable $\mathrm{X}_{1}$ and variable $\mathrm{Y}$ with a moderate effect category (0.40 - 0.599), implying that the principal's leadership style had an impact on teacher success. Furthermore, the standard error of prediction (standard deviation) refers to the deviation from the expected value. The standard deviation in this analysis was 3,898 . The model performs better when the standard deviation is low. The coefficient of determination analysis is used to calculate the percentage contribution of the variable's effect to the dependent variable. According to table 4.10, the number obtained by the coefficient of determination $R$ square $\left(R_{2}\right)$ is 0.353 , implying that the principal's leadership style $\left(\mathrm{X}_{1}\right)$ influences teacher efficiency (Y) by 35.3 percent.

In this analysis, the constant coefficient is 45,380 , and the coefficient number $\mathrm{X}_{1}$ is 0.486 , so we get a simple linear equation $=45,380+0.486 \mathrm{X}$, or the partial regression equation between the variables $\mathrm{X}_{1}$ and $\mathrm{Y}$ is $\mathrm{Y}=45,380+0.486 \mathrm{X}_{1}$. This equation is also used to describe the influence of the principal's leadership style $\left(\mathrm{X}_{1}\right)$ on teacher efficiency $(\mathrm{Y})$. 
The coefficient analysis provided a $\mathrm{t}$ count of 6,391. If tcount $>$ t table, then Ha is accepted; otherwise, if tcount is the number of independent variables). The results for $t$ table of 1.992 were obtained using a two-sided test ( significant $=0.025$ ).

Based on the explanation above, namely tcount $=6,391$ and t table 1,992, $\mathrm{t}$ count $>\mathrm{t}$ table, which means Ho is rejected and $\mathrm{Ha}$ is approved, or it is concluded that the principal's leadership style has a positive and significant impact on teacher results, especially teachers at SMAN 1 and SMKN 1 Rambutan.

\section{2) The impact of teacher motivation on student achievement}

The results of this study's analysis based on a simple linear regression analysis based on the output model description obtained the $\mathrm{R}$ number of 0.744 , indicating that the relationship between variable $X_{2}$ and variable $Y$ indicates a strong influence category $(0.60-0.799)$, so it is concluded that teacher motivation has a strong influence on success. Furthermore, the standard error of prediction (standard deviation) refers to the deviation from the expected value. The standard deviation in this analysis was 3.237.

The coefficient of determination analysis is used to calculate the percentage contribution of the variable's effect to the dependent variable. According to table 4:12, the number obtained by the coefficient of determination $\mathrm{R}$ square $\left(\mathrm{R}_{2}\right)$ is 0.554 , suggesting that teacher motivation $\left(\mathrm{X}_{2}\right)$ affects teacher efficiency (Y) by $55.4 \%$.

According to table 4.13, the constant coefficient number (constant) $=0.472$ and the coefficient number $\mathrm{X}_{2}=1.115$, resulting in the simple linear equation $=0.472+1.115 \mathrm{X}$ or the partial regression equation $\mathrm{Y}=0.472+1.115 \mathrm{X}_{2}$ between the variables $\mathrm{X}_{1}$ to $\mathrm{Y}$. This equation is also used to describe the influence of motivation $\left(\mathrm{X}_{2}\right)$ on teacher efficiency $(\mathrm{Y})$.

The coefficient analysis resulted in a tcount of 9,644. If tcount $>t_{\text {table, }}$, then Ha is accepted; otherwise, Ho is rejected and Ha is accepted; or it is concluded that there is a positive and significant influence between teacher motivation and teacher results, especially among teachers at SMAN 1 and SMKN 1 Rambutan.

\section{3) The impact of the principal's management style and teacher motivation on teacher success}

This research concludes that there is a strong influence between the powers based on the effects of multiple linear regression analysis based on the performance model description, the $\mathrm{R}$ number is 0.757 , which means that the relationship between the two, namely variable $\mathrm{X}$ to variable $Y$, which shows the category of strong influence (0.60-0.799), the R number is 0.757 , which means that the relationship between the two, namely variable $X$ to variable $Y$, which shows the category of strong influence ( 0.60 Furthermore, the standard error of prediction (standard deviation) refers to the deviation from the expected value. The standard deviation in this analysis is 3.187 .

The model performs better when the standard deviation is minimal.

The coefficient of determination analysis is used to calculate the percentage contribution of the variable's effect to the dependent variable. According to table 4.15, the number obtained by the coefficient of determination $\mathrm{R}$ square $\left(\mathrm{R}_{2}\right)$ is 0.573 , indicating that the principal's leadership 
Volume 2 (1) 2021

E-ISSN: 2723-6919 P-ISSN:2746-0827

style $\left(\mathrm{X}_{1}\right)$ and teacher motivation $\left(\mathrm{X}_{2}\right)$ are able to influence teacher efficiency $(\mathrm{Y})$ by contributing $57.3 \%$, with the remaining $42.7 \%$ clarified by other variables not included in this analysis.

Based on the results of the linear regression analysis of the t-test and f-test above, it can be addressed via the theoretical pattern of the research framework, the contribution of each variable $\mathrm{X}_{1}$ (principal leadership style) to variable $\mathrm{Y}$ (teacher performance) is $35.3 \%$, variable $\mathrm{X}_{2}$ (teacher motivation) to variable $\mathrm{Y}$ is $55.4 \%$, and variables $\mathrm{X}_{1}$ and $\mathrm{X}_{2}$ to $\mathrm{Y}$ is $57.3 \%$, with the remaining $42.7 \%$ affected by other factors not addressed in this report.

\section{Conclusion}

The following conclusions may be drawn based on the observations, discussion, and data analysis: 1) there is an impact of the principal's leadership style on performance, the value of the results is tcount $=6,391$ and ttable 1,992, then tcount $>$ ttable, which means Ho is rejected and $\mathrm{Ha}$ is approved, or it is concluded that there is a partially positive and important influence of the principal's leadership style on teacher performance, especially teachers at SMAN 1 and SMKN 1 Rambutan; 2) there is an impact of teacher motivation on results, with tcount $=9,644$ and ttable 1,992 indicating that tcount> ttable implies that Ho is rejected and $\mathrm{Ha}$ is accepted, or that par is concluded. 2) There is an impact of teacher motivation on performance, the value of tcount $=9,644$ and ttable 1,992 show that tcount $>$ ttable means that Ho is rejected and $\mathrm{Ha}$ is accepted, or it is concluded that there is a partially positive and important influence between teacher motivation and teacher performance, especially for teachers at SMAN 1 and SMKN 1 Rambutan, and 3) the principal's leadership style and teacher motivation have an impact on the success of the principles fcount $=49.615$ and ftable 3.21 , where fcount $>$ ftable implies that Ha is acknowledged. It is concluded that the principal's leadership style and teacher motivation both have a major positive impact on teacher performance.

\section{E. Acknowledgement}

We thank to the Principal of SMA-SMK Negeri in Rambutan Banyuasin Sub-District, Chancellor of the Universitas PGRI Palembang, Director of Graduate Program and the Education Management Study Program who have supported us to do this project. This project is independently funded. We would also like to thank our friends in who helped us a lot in completing this project.

\section{References}

Barnawi \& Arifin, M. (2014). Kinerja Guru Profesional [Professional Teacher Performance]. Yogyakarta: Ar-Ruzz Media.

Danim, S. (2012). Motivasi Kepemimpinan dan Efektivitas Kelompok [Leadership Motivation and Group Effectiveness]. Jakarta: Rineka Cipta.

Dharma, K. (2011). Pendidikan Karakter Kajian Teori dan Praktik di Sekolah [Character Education in Theory and Practice Studies in Schools]. Bandung: Remaja Rosdakarya.

Duhou, I. A. (2012). School-Based Management. Jakarta: Logos.Ekonisia. 
Journal of Social Work and Science Education

Volume 2 (1) 2021

E-ISSN: 2723-6919 P-ISSN:2746-0827

Emzir. (2014). Metodologi Penelitian Kualitatif Analisis Data [Qualitative Research Methodology for Data Analysis]. Cet. 4. Jakarta: Rajawali Pers.

Fattah, N. (2011). Landasan Manajemen Pendidikan [Educational Management Foundation]. Bandung: Remaja Rosdakaarya.

Fattah, H. A. (2019). Kepuasan Kerja dan Kinerja Pegawai [Job Satisfaction and Employee Performance]. Yogyakarta: Elmatera (Anggota IKAPI).

Kurniadin, D., \& Machali, I. (2014). Manajemen Pendidikan Konsep dan Prinsip Pengelolaan Pendidikan [Educational Management Concepts and Principles of Educational Management]. Yogyakarta: Ar-Ruzz Media.

Poerwadarminta, W. (2011). Kamus Umum Bahasa Indonesia [General Indonesian Dictionary]. Jakarta: Balai Pustaka.

Ramadoni, W. (2014). Kepemimpinan Kepala Sekolah dalam Upaya Peningkatan Kinerja Guru di SD Negeri Tanjung Sari I Sidoarjo [Leadership of Principals in Efforts to Improve Teacher Performance at SD Negeri Tanjung Sari I Sidoarjo]. Jurnal Inspirasi Manajemen Pendidikan Vol. 3 No. 3.

Sagala, S. (2012). Administrasi Pendidikan Kontemporer [Contemporary Educational Administration]. Bandung: Alfabeta.

Sardiman. (2012). Interaksi dan Motivasi Belajar Mengajar [Teaching and Learning Interaction and Motivation]. Jakarta: Rajawali Pers.

Sutrisno. (2012). Manajemen Keuangan Teori, Konsep dan Aplikasi [Financial Management Theory, Concepts and Applications]. Yogyakarta: Fakultas Psikologi UGM.

Sujanto, B. (2018). Pengelolaan Sekolah: Permasalahan dan Solusi [Financial Management Theory, Concepts and Applications]. Jakarta: Bumi Aksasa.

Thoha, M. (2019). Kepemimpinan dalam Manajemen [Leadership in Management]. Depok: Rajawali Pers.

Tirtarahardja, U., \& Sulo, S. (2015). Pengantar Pendidikan [Introduction to Education]. Jakarta: Rineka Cipta. 